\title{
UNIVERSITYOF
}

FORWARD

THINKING

WESTMINSTER用

WestminsterResearch

http://www.westminster.ac.uk/westminsterresearch

Airport route development: a survey of current practice

Halpern, N. and Graham, A.

NOTICE: this is the authors' version of a work that was accepted for publication in Tourism Management. Changes resulting from the publishing process, such as peer review, editing, corrections, structural formatting, and other quality control mechanisms may not be reflected in this document. Changes may have been made to this work since it was submitted for publication. A definitive version was subsequently published in Tourism Management, 46, p. 213-221, 2015.

The final definitive version in Tourism Management is available online at:

https://dx.doi.org/10.1016/j.tourman.2014.06.011

(c) 2015. This manuscript version is made available under the CC-BY-NC-ND 4.0 license http://creativecommons.org/licenses/by-nc-nd/4.0/

The WestminsterResearch online digital archive at the University of Westminster aims to make the research output of the University available to a wider audience. Copyright and Moral Rights remain with the authors and/or copyright owners.

Whilst further distribution of specific materials from within this archive is forbidden, you may freely distribute the URL of WestminsterResearch: ((http://westminsterresearch.wmin.ac.uk/)).

In case of abuse or copyright appearing without permission e-mail repository@westminster.ac.uk 


\section{AIRPORT ROUTE DEVELOPMENT: A SURVEY OF CURRENT PRACTICE}

\section{Introduction}

Airports were traditionally considered to be public utilities, and focused largely on facilitating the safe and efficient movement of aircraft and passengers rather than commercial considerations. Airport operators adopted a fairly passive approach to marketing, doing relatively little to encourage customers to use their services. However, in many parts of the world, airports have become more commercially orientated. This, combined with airline liberalisation in many markets, has led to a much more competitive airport industry (Thelle et al., 2012; Forsyth et al., 2010). As a result, marketing has become a core activity at many airports, and one that is considered to be vital for success (Halpern and Graham, 2013).

An airport has many customers but two of the most important are airlines and passengers, and the marketing techniques used for the two types of customer vary (Graham, 2014). Airports tend to use traditional approaches when marketing to passengers such as providing electronic and printed information, advertising through a range of media, developing loyalty programmes, offering sponsorship, and holding fundraising events and air shows. However, the extent to which an airport operator by itself can influence a passenger's choice is limited as their decision is primarily determined by the airline services on offer and the location of the airport. Instead, many airports direct much of their attention towards marketing to airlines, and this can arguably have a more significant impact on the success of an airport.

ASM (2009) found that 96 per cent of all European airports are actively involved in marketing their airport to airlines. This includes the use of common approaches such as providing publicity information or launching advertising campaigns that create awareness and communicate general messages about the airport. However, in recent years, airports have increasingly used personal selling as a means of targeting specific airlines with the aim of developing a deeper relationship with them. Route development (also known as air service development in some countries) underpins the targeted approach to personal selling. It is a process that seeks to "demonstrate to air carriers that there is sufficient demand, and suitable airport facilities, to profitably operate a route from the airport" (Tretheway and Kincaid, 2010; p.133).

Route development is now a well-known concept within the airport industry, and has been accompanied by a growing number of specialist route development consultants. Surprisingly, it has received limited attention in academic or industry literature. This means that little knowledge is shared about why airports use route development, what are the most common methods used, and what resources airports dedicate to it. To fill the gap, this research investigates airport route development practice based on the findings of an online survey of 124 airports worldwide. The findings can be used by airport management to further develop their own route development strategy and to learn from best practice. Whilst many airport stakeholders can be involved with route development such as regional economic development agencies, destination management organisations or tourism authorities, and Chambers of Commerce or other business associations, the focus of this research is on the airport operator's use of route development.

The structure of this paper is as follows. Section 2 discusses the principles of route development, drawing from the limited literature available on the topic. Section 3 briefly describes the methodological approach taken in terms of survey design, sampling and 
analysis. Section 4 presents the main findings of the survey. Section 5 concludes and discusses the implications of the research.

\section{Principles of route development}

\subsection{The objectives of route development}

Route development has been explained in a number of ways. Thelle et al. (2012, p.81) define it as the "marketing activities undertaken by airports with the aim of attracting new routes, for example through participation in route development conferences, offering incentive schemes, meetings with airlines, producing bespoke reports for airlines". Martin (2009, p.v) states that it "includes the attraction, initiation, expansion, retention, or any improvement of air service and can include changes in pricing, frequency, capacity, hub connectivity, or the number of nonstop destinations served". These two descriptions demonstrate the wide ranging nature of route development, both in terms of its objectives and the methods used. This is not fully apparent with the name itself which arguably suggests a somewhat narrower and simpler approach.

The most obvious objective of route development is to encourage new airlines to an airport to operate new routes. Indeed, Kramer et al. (2010) identify the air service development cycle where new services grow the traffic, which in turn makes the market more attractive and attracts more services. However, in reality, route development can have a number of different purposes including attracting new routes with new airlines, but also growing existing routes, attracting new routes with existing airlines, retaining existing routes and influencing change to existing routes (e.g. lowering fares, changing schedules, reducing seasonality, upgrading aircraft).

There is very little evidence in the literature to help determine the relative importance of the different objectives. An exception is a survey of 41 small and non-hub airports in the US as reported by Martin (2009). Eighty per cent of airports stated that they used route development techniques to retain existing services and over 70 per cent declared that they used it to add services to new destinations or add frequencies at the airport. Around 60 per cent used it to reduce fares, whereas just under half used it to improve services and only around a third to upgrade the aircraft used.

STRAIR (2005) divides the objectives into two types, namely those related to connectivity (number of destinations served, frequencies and capacity) and those related to traffic (number of passengers arriving, departing and transiting, cargo value, weight and volume). The type of service being targeted may also vary considerably. It can be considered by airline (e.g. mainline, low cost, regional, leisure/tourism charter, private/business charter) or destination (e.g. domestic, international within the same world region, intercontinental). In addition, cargo flights can be specifically targeted but, as de Haan (2012) argues, this can be more challenging because of the different markets and airline business models, together with the relatively poor quality of data. Depending on the nature of the airport operator and the relationship with stakeholders in the surrounding community, there may be broader and complex objectives related to wider benefits for the region such as the development of tourism or improved connectivity for businesses or local residents.

ASM (2009) conducted a survey of about 100 airports in 2008 and found that within Europe, over 74 per cent of airports focused their route development efforts on short-haul services 
whilst 49 per cent focused on long-haul. By contrast, for airports in the rest of the world, 66 per cent concentrated on long-haul services and 54 per cent on short-haul. Low cost carrier flights were of particular interest for 72 per cent of European airports and 66 per cent of other airports. In addition, some indication of the priorities of airport route development can often be observed on the business-to-business section of airport websites, where information or published price incentives demonstrate the airport's favoured route developments. For example, with airports as diverse as Dublin, Prague, Phoenix Sky Harbor, Macau and Bergen, there are more generous incentives offered for intercontinental or long-haul services (Halpern and Graham, 2013).

Whatever the objectives are for airport route development, they have to be realistic in terms of the demand that can be generated at the airport, the airport infrastructure and services that are offered, and the availability of airlines that are willing and able to operate the services that are being proposed.

\subsection{The route development process}

In order to be successful in route development, a considerable amount of marketing research is needed to be undertaken by the airport operator. Halpern and Graham (2013) describe how this is needed to support the following stages in the route development process: define catchment area; undertake market assessment; identify unserved or underserved routes; produce growth forecast for potential routes; choose possible airlines to operate the routes; and undertake a financial viability assessment of the route. Martin (2009) and STRAIR (2005) discuss the processes in a similar way. The data requirements for such an exercise can be substantial. Not only will use be made of internal airport data and surveys, national travel and tourism statistics, but also true origin and destination demand and schedule data such as is provided by Sabre, OAG, the International Air Transport Association (IATA) or the International Civil Aviation Organization (ICAO). These sources can be used as a basis for estimating market shares and forecasts, and for considering the financial feasibility of the routes. Various methodologies can be applied with one of the more sophisticated estimation models being the quality service index (QSI), which assesses passenger behaviour by quantifying the relative attractiveness of different flight options (Weatherill, 2009).

Once the appropriate research has been undertaken, the airport operator needs to decide how it can communicate this information to airlines, and demonstrate the prospects for new routes or expanding services at the airport. Relationship building between the airport operator and airline is important for route development (Griffin, 2012). Traditionally, this was undertaken by setting up individual meetings with airlines, with a bespoke report written for them, but now a number of alternatives exist. This includes route development networking events such as Routes, Jumpstart or French Connect, which provide opportunities for one-to-one meetings between airport operators and airlines. There are also route development websites such as The Route Shop and Route Exchange. The survey by ASM (2009) showed that 93 per cent of airport operators attended networking events and 82 per cent visited airline offices to undertake presentations. By contrast only around half of the airports used route development websites, but these have developed considerably since the survey was undertaken in 2008.

Regardless of the methods used to communicate with airlines, airports need to provide the essential information that airlines need to encourage them to use the airport. In addition to route forecasts and financial evaluations, this includes information on catchment area characteristics, airport facilities, and any price incentives or marketing support that is 
available. ASM (2013) present the results of a rare survey of 25 senior network planning managers from leading global airlines. On a scale of 10 (essential) and 0 (not important), information provision, catchment area characteristics, and demographics data had an average score of 9, whilst a profit and loss assessment of the route proposal had an average score of 4 . This prompted Stroud $(2013$, p.60) to argue that "The days of trying to impress an airline with an appreciation of route profit and loss are over".

The survey by ASM (2013) also confirmed the importance of incentives and risk-sharing initiatives offered by airport operators to airlines. This has traditionally been viewed as an important requirement for airports seeking to attract low cost airlines, for instance, by entering into negotiations on price with them (Graham, 2013; Barrett, 2004), and offering discounted charges for use of the airport (Francis et al., 2003), although the enduring nature of the low cost model has been questioned in recent years (e.g. see Budd et al., 2014; Button, 2012). Besides, incentives offered by airports should be made available to all types of airlines that meet the required criteria, regardless of their business model.

STRAIR (2005) divide incentives as financial or non-financial. Financial incentives cover direct payments (payments per flight or passenger and marketing budget); discounts on airport charges, property rental and taxation; and risk sharing arrangements (revenue guarantees, travel banks and joint ventures). Malina et al. (2011) found that 63 per cent of Europe's 200 largest airports offer incentives of some kind to airlines, whilst a survey of 52 airports in the US found that 65 per cent of airports offer incentive schemes or agreements for domestic air services and 48 per cent for international (Hargrove, 2010). Financial incentives have generally received more coverage in the literature (e.g. see Fichert and Klophaus, 2011; Weatherill, 2006). This is partly because the specific details of financial incentives are often in the public domain, but also because they can be an area of controversy if public money is involved. By contrast, non-financial incentives include providing regulatory and market information; providing contacts to feeder airlines, service providers, agents and the media; helping the airport operator to provide a good level of service to airlines; and helping other stakeholders serve airlines better.

\subsection{The importance of route development}

The discussion thus far has detailed how route development has become a key activity in today's airport business. It is therefore surprising that little is known about the typical manpower or resources that are devoted to it. A rare indication is demonstrated in the previously mentioned survey of small and non-hub airports in the US (Martin, 2009). The median cost in 2007 for each airport was estimated to be US\$70,000 for core resources covering salaries associated with route development, data costs and other normal expenses such as conference attendance and travel costs to visit airlines. In addition, a further US $\$ 100,000$ of extra costs per airport covered particular types of incentive programmes such as minimum revenue guarantees, subsidies and other marketing efforts.

The survey by Martin (2009) concentrated on small airports, which actually has been the focus of most of the limited research on route development (e.g. see Halpern, 2010). Arguably, it is these airports that face the greatest challenges in, but also rewards from, attracting airlines and improving the provision of air services. In terms of geographical regions, the survey by ASM (2009) found that European airports were generally more proactive in their approach to route development than airports in other world regions. This may be as a result of a more competitive and commercially oriented airport industry in Europe, 
with the existence of a number of privatised airports. On the other hand, publicly owned airports may be more prepared to offer generous incentives to help bring wider benefits to surrounding communities.

This raises the issue of other stakeholder involvement in route development. So far the discussion has focused on the airport operator's role, and this will be the emphasis of the research here. However, as already identified there will be other stakeholders who may seek to be involved. This may be the national government, for example in Malta in 2006, where fee discounts were introduced to support new routes and encourage different types of tourists, by both the government and by the airport operator (Graham and Dennis, 2010). Destination management organisations may also be involved, as is the case with Global Connected; a consortium consisting of Copenhagen Airport and a number of destination management organisations in Denmark, that seeks to strengthen air service provision at the destination by influencing airline route decisions with the offer of funding for marketing campaigns (Hvass, 2013).

A survey by ASM identified tourism authorities as being the most popular partners for route development (87 per cent), followed by local and city authorities and private partnerships (56 per cent), private business development interests (e.g. Chamber of Commerce) (50 per cent), regional development governmental organisations (47 per cent), and regional development non-governmental organisations (22 per cent) (ASM, 2009).

Airport growth should benefit both the region and the airport. However, if an airport operator enters into a partnership, there may be a shift of emphasis to supporting routes that appear to have the greatest economic benefit to the region rather than greatest revenue potential for the airport, for instance, by encouraging routes that will increase business connectivity or inbound tourism. Financial incentives to airlines are often viewed as being important here (Castillo-Manzano et al., 2011). For example, Scotland's Route Development Funds were financed by regional development agencies to encourage traffic that offers regional economic benefits (Smyth at al., 2012). Similarly in the US, there is the Small Community Air Service Development Program which provides grants to help small communities attract air services. However, the effectiveness of such schemes has been debated on the basis that routes may be closed after the funding period has come to an end (Pagliari, 2005).

Having introduced the key principles of route development, drawing on the limited and somewhat patchy research that exists, the rest of this paper focuses on the airport survey that was undertaken with the aim of gaining a greater knowledge and understanding of the issues that have been identified.

\section{Methodology}

\subsection{Survey design}

The survey was administered online using the Questback Ask and Act survey tool. It consisted of twenty-six, largely closed questions, relating to the three broad areas mentioned in Section 2: (1) The objectives of route development; (2) The route development process; (3) The importance of route development. For instance, the literature review in Section 2.1 suggests that airport route development has broad objectives that include attracting new routes with new or existing airlines, retaining or growing existing routes, or influencing change to existing routes (for instance, to fares, schedules or aircraft). Literature also suggests 
that airports may have more specific objectives for route development that target particular types of airlines (e.g. mainline, low cost, regional, leisure/tourism charter or private/business charter) or destinations (e.g. domestic, international within the same world region or intercontinental). The survey questions were therefore designed to measure the relative importance of such objectives.

The survey was written in English. A participating pre-test of the survey was carried out with 16 experts from industry and academia that have specialist knowledge of airport route development. Respondents were told that it was a draft version of the survey and were asked to provide feedback on the relevance, order and wording of questions, the length of the survey, ease of completion, and any technical issues associated with accessing and completing the survey. Respondents were also asked to provide feedback on the wording of an invitation email that would be sent to airports when inviting them to participate in the survey. Feedback from the participating pre-test resulted in only minor changes, for instance, to the wording of a few questions and the invitation email.

An undeclared pre-test of the revised and final version of the survey was then carried out by sending the survey to managers at five airports that were known to the authors and therefore likely to respond. The survey was delivered in exactly the same way as the actual survey and respondents were not told that it was a pre-test. Responses were received from four airports. This is a limited number of responses, but was sufficient to check the standardisation of the survey.

The survey was then delivered to a gross sample of 934 airports. A URL link to the survey was sent to airports in an invitation email during week 42 (21-28 October) in 2013. Two repeat mailings were sent during weeks 44 and 45 . The invitation email provided a salutation and a brief introduction to the aim of the survey, the selection criteria and sample of airports, how the findings would be used, and details of the research team in case recipients had any comments or questions. The invitation email emphasised the anonymous nature of the survey stating that responses will remain strictly confidential and that the analysis will not identify responses from individual airports. A free copy of the book Airport Marketing was offered as a prize to 20 respondents selected at random as an incentive to take part in the survey. A free summary of the findings was also offered. The invitation email included an option that airports could select if they wished to decline from participating in the survey.

\subsection{Sampling and analysis}

Flightglobal Pro was used as a sampling frame for the population of world airports. It is a leading information source for the aviation industry, and at the time of conducting this study, provided profiles for 1791 airports worldwide. As selection criteria, only airports on Flightglobal Pro with a complete profile including an email address and traffic data for the most recent year; 2012, were included. This resulted in a gross sample of 934 airports. Most of the airport email addresses on Flightglobal Pro are for the general administration of the airport operator, so where possible, airport websites were searched in order to find an email address for named route development personnel or other named personnel (largely airport managers or media contacts).

The net sample represents the respondents to the survey. Responses were received from 124 airports resulting in a gross sample response rate of 13 per cent. This is exactly the same response rate experienced in an earlier study of airports that used a similar methodological 
approach to this study, but investigated the provision and use of meeting facilities at airports, rather than airport route development practice (see Halpern et al., 2012). The low response rate and low overall number of responses is a limitation, however, it is characteristic of studies of this nature. As mentioned in Section 2, the survey on passenger air service development at small and non-hub airports in the US, which is cited in Martin (2009), received responses from just 41 airports. ASM (2009) received responses from about 100 airports worldwide to their survey on airport route development strategies.

A greater proportion of responses were received from named route development personnel compared to other named personnel or the general administration. Twenty-one per cent of email addresses for airports in the gross sample were for named route development personnel, 33 per cent for other named personnel, and 46 per cent for the general administration.

However, 48 per cent of responses were from email addresses for named route development personnel, 28 per cent for other named personnel, and 24 per cent for the general administration.

Bias is present in the net sample of respondents according to airport size (measured by total passengers served in 2012) and the geographic location of airports (see Table 1). The net sample has a greater proportion of mid-sized airports, and airports from Europe and North America - possibly because they are more active in route development, and therefore more interested in taking part in the survey. The findings of the survey are therefore biased towards those airports. Only net sample data has been provided for ownership of the airport operator in Table 1 due to difficulties in finding accurate data for the population and gross sample.

Table 1

Samples by airport characteristics (per cent).

\begin{tabular}{lllll}
\hline Airport characteristic & $\begin{array}{l}\text { Sampling } \\
\text { frame }\end{array}$ & $\begin{array}{l}\text { Gross } \\
\text { sample }\end{array}$ & $\begin{array}{l}\text { Net } \\
\text { Sample }\end{array}$ & $\begin{array}{l}\text { Difference } \\
\text { (net - frame) }\end{array}$ \\
\hline $\begin{array}{l}\text { Size (total passengers, 2012) } \\
\text { <1 million }\end{array}$ & 66.4 & 50.1 & 47.6 & $(18.8)$ \\
1 million to <5 million & 18.6 & 26.8 & 29.0 & 10.4 \\
5 million to <25 million & 11.7 & 17.3 & 18.6 & 6.9 \\
25 million or more & 3.3 & 5.8 & 4.8 & $(1.5)$ \\
Region & & & & \\
Africa & 7.6 & 6.0 & 1.6 & $(6.0)$ \\
Asia/Pacific & 21.4 & 12.3 & 7.3 & $(14.1)$ \\
Europe & 32.4 & 48.7 & 58.1 & 25.7 \\
Latin America/Caribbean & 12.8 & 7.6 & 3.2 & $(9.6)$ \\
Middle East & 2.1 & 2.7 & 1.6 & $(0.5)$ \\
$\quad$ North America & 23.7 & 22.7 & 28.2 & 4.5 \\
Ownership of the airport operator & & & & \\
Public, administration & - & - & 40.3 & - \\
Public, corporation & - & - & 38.7 & - \\
$\quad$ Mixed public/private & - & - & 9.6 & - \\
Fully private & - & - & 11.3 & - \\
\hline
\end{tabular}

Findings from the survey are largely analysed using frequency analysis of responses. Some responses are analysed using inferential statistics to investigate differences, for instance, in responses to questions according to size or geographic location of the airport, or ownership of the airport operator. Tests that have been used are dependent on the variables under consideration and include the Independent Samples t-test, One-Way Analysis of Variance (ANOVA), and Pearson's Chi-Square. Only results that meet the specific criteria of each test and produce significant differences $(\mathrm{p}<0.05)$ are reported in this paper. In order to optimise 
the number of cases in each sub-group, dichotomous categories were created for certain variables. Airport size is dichotomised between smaller airports (with less than one million passengers per annum) and larger airports (with one million or more). Ownership of the airport operator is dichotomised between public airports (with a full publicly owned operator) and private airports (with an operator that is owned by at least part private interests).

One question in the survey asks respondents about the extent to which they have used different ways to communicate route development opportunities to airlines during the last 12 months. The question lists ten items (ways of communication) that can be combined to provide an indication of the overall extent to which respondents communicate route development opportunities to airlines. Scale reliability of the ten items is tested using Cronbach's Alpha, which determines the internal consistency of the items.

The first question in the survey asked respondents if their airport had pursued route development objectives during the last 12 months. Six per cent of respondents answered no. The findings of this study are based only on respondents that answered yes.

\section{Findings}

\subsection{The objectives of route development}

Airports pursue a range of route development objectives (see Table 2). The greatest focus is on the more challenging and high-risk objective of attracting new routes with new airlines. Airports also have a strong focus on growing existing routes, attracting new routes with existing airlines, and retaining existing routes. Larger airports are significantly more focused on attracting new routes with new and existing airlines compared to smaller airports. This may of course be due to there being greater opportunities to attract new routes at larger airports because of their higher level of potential demand. The least focus is on influencing change to existing routes, which is likely to be more of an airline function. Of those that have concentrated on influencing change to existing routes, the greatest focus of change is to frequency ( 87 per cent of respondents), followed by timing ( 62 per cent), aircraft type ( 56 per cent), fare (35 per cent), and reliability/punctuality ( 29 per cent).

Table 2

Extent to which airports have pursued the following objectives for route development during the last 12 months.

\begin{tabular}{|c|c|c|c|c|c|c|c|}
\hline \multirow[b]{2}{*}{ Objective } & \multirow[b]{2}{*}{$\mathrm{N}$} & \multicolumn{4}{|c|}{ \% Respondents } & \multirow[b]{2}{*}{ Mean } & \multirow[b]{2}{*}{ SD } \\
\hline & & $\begin{array}{l}\text { Great } \\
\text { extent }\end{array}$ & $\begin{array}{l}\text { Some } \\
\text { Extent }\end{array}$ & $\begin{array}{l}\text { Very } \\
\text { little }\end{array}$ & $\begin{array}{l}\text { Not } \\
\text { at all }\end{array}$ & & \\
\hline Attract new routes with new airlines ${ }^{\text {a }}$ & 116 & 62 & 33 & 3 & 2 & 1.5 & .651 \\
\hline Attract new routes with existing airlines ${ }^{b}$ & 115 & 57 & 32 & 6 & 5 & 1.6 & .825 \\
\hline Grow existing routes & 115 & 58 & 29 & 9 & 4 & 1.6 & .826 \\
\hline Retain existing routes & 115 & 50 & 31 & 16 & 3 & 1.7 & .827 \\
\hline Influence change to existing routes & 113 & 27 & 39 & 23 & 11 & 2.2 & .953 \\
\hline
\end{tabular}

Mean $=1$ 'great extent', 2 'some extent', 3 'very little', 4 'not at all'.

Significant difference in means according to the Independent Samples t-test:

a Smaller (mean 1.6, N 52, SD .771), larger (mean 1.3, N 64, SD .500), t(114)2.552, p.012.

b Smaller (mean 1.9, N 51, SD 1.005), larger (mean 1.4, N 64, SD .545), t(113)3.693, p.000.

The greatest focus of route development is on scheduled passenger services provided by mainline, low cost and regional airlines (see Table 3). Airports are less focused on leisure/holiday charters, and less still on cargo, which tends to be a niche market for a small 
proportion of airports. The greatest focus is also on international and domestic services rather than intercontinental (see Table 4).

Table 3

Extent to which airports have focused on developing the following types of air service during the last 12 months, by airline.

\begin{tabular}{|c|c|c|c|c|c|c|c|}
\hline \multirow[b]{2}{*}{ Airline } & \multirow[b]{2}{*}{$\mathrm{N}$} & \multicolumn{4}{|c|}{$\%$ Respondents } & \multirow[b]{2}{*}{ Mean } & \multirow[b]{2}{*}{ SD } \\
\hline & & $\begin{array}{l}\text { Great } \\
\text { Extent }\end{array}$ & $\begin{array}{l}\text { Some } \\
\text { Extent }\end{array}$ & $\begin{array}{l}\text { Very } \\
\text { little }\end{array}$ & $\begin{array}{l}\text { Not } \\
\text { at all }\end{array}$ & & \\
\hline Scheduled mainline $^{a}$ & 116 & 52 & 32 & 6 & 10 & 1.8 & .968 \\
\hline Scheduled low cost ${ }^{b}$ & 116 & 47 & 25 & 15 & 14 & 2.0 & 1.083 \\
\hline Scheduled regional & 116 & 45 & 36 & 15 & 4 & 1.8 & .853 \\
\hline Leisure/holiday charter & 116 & 29 & 39 & 23 & 9 & 2.1 & .930 \\
\hline $\mathrm{Cargo}^{\mathrm{c}}$ & 114 & 10 & 17 & 33 & 41 & 3.1 & .985 \\
\hline $\begin{array}{l}\text { Mean = 1 'great extent', } \\
\text { Significant difference in } \\
\text { a Smaller (mean 2.2, N } 5 \\
\text { b Smaller (mean 2.4, N } 5 \\
\text { c Smaller (mean 3.5, N } 5\end{array}$ & $\begin{array}{l}\text { 'some } \\
\text { eans } \\
\text { SD } 1 \\
\text { SD } 1 \\
\text { SD }\end{array}$ & $\begin{array}{l}\text { xtent', } 3 \\
\text { cording t } \\
\text { 99), large } \\
\text { 86), large } \\
\text { 8) laroer }\end{array}$ & $\begin{array}{l}\text { very littl } \\
\text { the Inde } \\
\text { (mean } 1\end{array}$ & , 4 'no & $\begin{array}{l}\text { all'. } \\
\text { amples } \\
\text { D .63( } \\
\text { D .88 } \\
1.01(\end{array}$ & test: & \\
\hline
\end{tabular}

Table 4

Extent to which airports have focused on developing the following types of air service during the last 12 months, by destination.

\begin{tabular}{llllllll}
\hline & & \multicolumn{5}{c}{ \% Respondents } & \\
\cline { 3 - 6 } & & Great & Some & Very & Not \\
Destination & $\mathrm{N}$ & extent & Extent & little & at all & Mean & SD \\
\hline Domestic & 116 & 47 & 20 & 14 & 20 & 2.1 & 1.185 \\
International (same world region) $^{\mathrm{a}}$ & 116 & 56 & 28 & 7 & 10 & 1.7 & .962 \\
Intercontinental $^{\mathrm{b}}$ & 115 & 25 & 17 & 19 & 38 & 2.7 & 1.221 \\
\hline
\end{tabular}

Mean $=1$ 'great extent', 2 'some extent', 3 'very little', 4 'not at all'.

Significant difference in means according to the Independent Samples t-test:

a Smaller (mean 2.0, N 52, SD 1.146), larger (mean 1.4, N 64, SD .687), $t$ (114)3.383, p.001.

b Smaller (mean 3.5, N 52, SD .804), larger (mean 2.0, N 63, SD 1.092), t(113)8.162, p.000.

As seen in Table 3 and 4, the focus of airports varies according to airport size. Smaller airports are more focused on regional and leisure/holiday charter services (although the result was not significant) while larger airports are significantly more focused on mainline, low cost and cargo services, and to foreign destinations. This is to be expected given the more limited market and potential for demand at smaller airports, which means that their focus is more likely to be on regional airlines that operate smaller aircraft or leisure/holiday charter services that tend to operate on a seasonal and less frequent basis. The latter allows tour operators to fill larger aircraft at peak periods on inbound or outbound services to tourism destinations.

The focus of larger airports on scheduled mainline or low cost services to foreign destinations is reflective of the larger markets that they serve and the greater potential for demand. Focusing on operators of larger aircraft and longer routes provides the opportunity to serve more passengers per aircraft movement - something that is particularly important for airports that have capacity constraints (e.g. on slots or runway use). It also generates increased passenger throughput and longer dwell time in the terminal, which subsequently offers opportunities for increased commercial revenues from passenger expenditure (e.g. in shops, cafes and restaurants).

The focus of airports also varies according to geographic location (see Table 5) and reflects the size of countries and also distances between borders in the respective world regions. For instance, airports in North America and Asia/Pacific - continents with a number of large 
countries and long distances between them - are significantly more focused on domestic services whilst airports in Europe - where there are many small countries with relatively short distances between them - are more focused on international services within the same world region. Care should however be taken when interpreting the results in Table 5 due to the small number of respondents from world regions other than Europe and North America. Results for Latin America/Caribbean are based on only four responses and three of those are for airports in the Caribbean. Similarly, six of the eight responses for Asia/Pacific are for airports in Australia or New Zealand.

Table 5

Extent to which airports have focused on developing the following types of air service during the last 12 months, by geographic location.

\begin{tabular}{llllllllll}
\hline & \multicolumn{1}{c}{ Domestic $^{\mathrm{a}}$} & \multicolumn{4}{c}{ International $^{\text {(same world region) }}{ }^{\mathrm{b}}$} & \multicolumn{3}{c}{ Intercontinental } \\
Geographic location & $\mathrm{N}$ & Mean & $\mathrm{SD}$ & $\mathrm{N}$ & Mean & SD & $\mathrm{N}$ & Mean & SD \\
\hline Africa & 2 & 2.5 & .707 & 2 & 2.0 & .000 & 2 & 2.5 & .707 \\
Asia/Pacific & 8 & 1.3 & .463 & 8 & 2.0 & 1.309 & 8 & 2.6 & 1.302 \\
Europe & 70 & 2.5 & 1.188 & 70 & 1.4 & .754 & 69 & 2.7 & 1.266 \\
Latin America/Caribbean & 4 & 3.0 & 1.414 & 4 & 1.3 & .500 & 4 & 1.3 & .500 \\
Middle East & 1 & 4.0 & - & 1 & 1.0 & - & 1 & 3.0 & - \\
North America & 31 & 1.2 & .454 & 31 & 2.3 & 1.125 & 31 & 3.0 & 1.110 \\
\hline
\end{tabular}

Mean $=1$ 'great extent', 2 'some extent', 3 'very little', 4 'not at all'.

Significant difference in means according to ANOVA: a $f(5,110) 9.816, \mathrm{p} .000 .{ }^{\mathrm{b}} f(5,110) 4.031, \mathrm{p} .002$.

\subsection{The route development process}

As suggested in Section 2, marketing research plays an important role in the route development process. Ninety-five per cent of airports stated that they had provided and presented airlines with market research to prove potential for route development during the last 12 months; 60 per cent 'to a great extent', although that figure varies according to airport size with 52 per cent for smaller airports compared to 77 per cent for larger airports. The more limited internal resources and expertise at smaller airports is likely to be a key constraint here.

National statistics offices are the most widely used individual source of data for airport route development purposes, and are a useful and often free source of data on catchment area characteristics. Collectively, the most widely used sources are of true origin and destination demand and schedules data such as Sabre, OAG, IATA, Innovata, ICAO and DIIO (see Fig. 1). Published forecasts and reports and national aviation authority data such as from a civil aviation authority or government department are also widely used. A large proportion of airports have used 'other' sources including government/immigration records, BEONTRA, data from consultants, internal airport records, MIDT, ARC, CAPA, Data Miner, Flightglobal, travel surveys, tourism/Chamber of Commerce data, IATA PaxIS and PTM data. Most airports use a range of data sources for route development purposes. Almost 85 per cent have used two or more of the sources listed in Fig. 1, whilst almost 20 per cent have used five or more. 


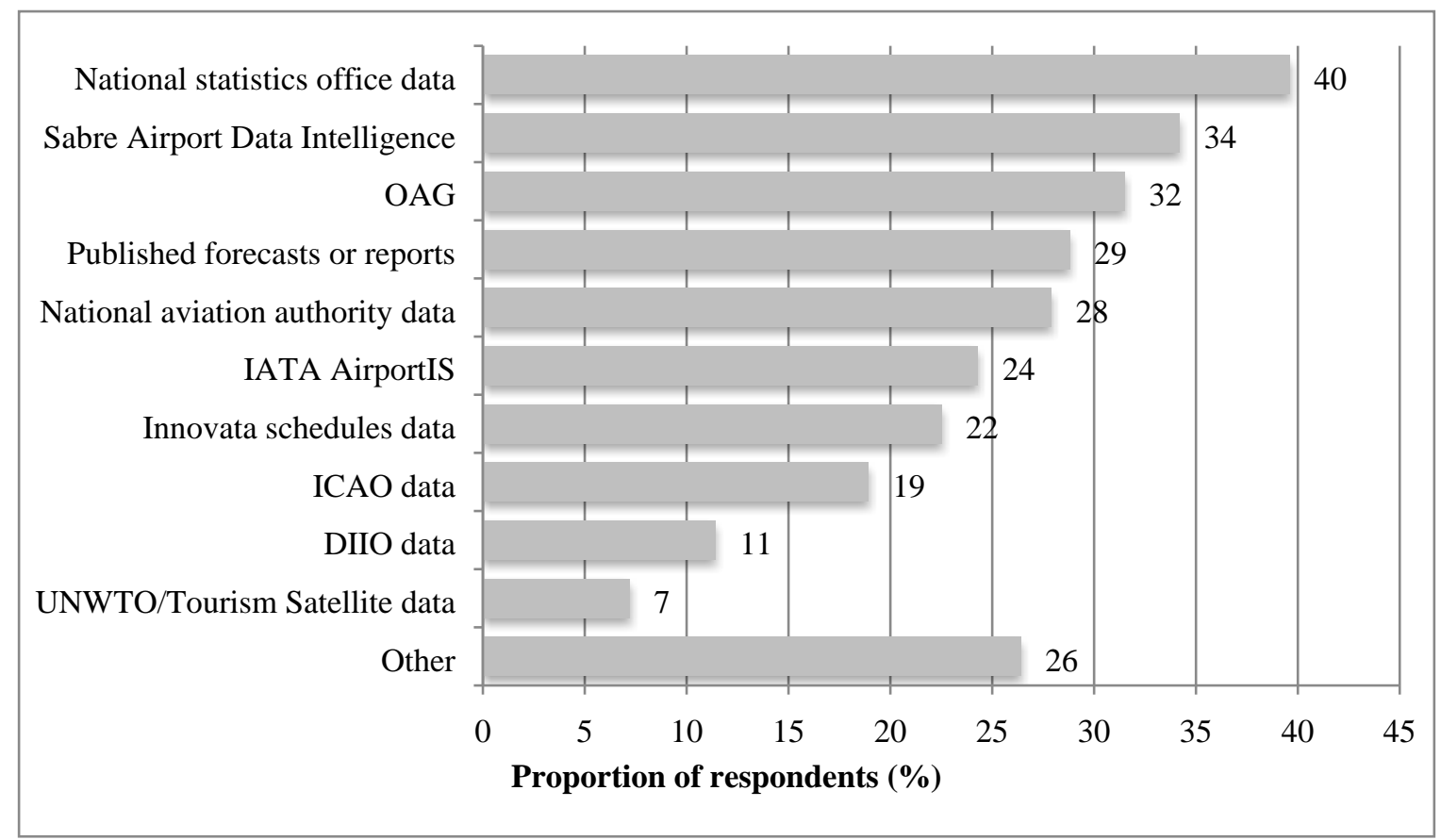

Fig. 1. Data sources used by airports for route development purposes during the last 12 months.

Airports then use a range of tools to analyse the data. Almost 90 per cent of respondents have used at least one tool during the last 12 months. The most common tool used by 71 per cent of respondents is a market stimulation forecast - a forecast that is typically based on knowledge of similar routes, 51 per cent used traffic allocation models (e.g. for route opportunities that compete with existing routes at local competing airports), and 38 per cent used QSI or connection builders (e.g. for assessing connecting traffic potential versus competing hubs). Sixty-four per cent of respondents also used surveys during the last 12 months to identify opportunities for route development. The most common groups surveyed by airports are passengers ( 88 per cent of respondents), businesses ( 60 per cent), airlines ( 28 per cent), travel trade ( 26 per cent), and residents ( 25 per cent).

After researching and identifying a specific route development opportunity, airports need to communicate it to target airlines (see Table 6). Active and targeted forms of personal selling are used most by airports such as attending route development networking events, seeking to meet airlines in their office and present to them, and targeting a specific airline and producing a bespoke report for them.

Table 6

Extent to which airports have used the following ways to communicate route development opportunities to airlines during the last 12 months.

\begin{tabular}{|c|c|c|c|c|c|c|c|c|}
\hline & \multirow[b]{2}{*}{$\mathrm{N}$} & \multicolumn{4}{|c|}{$\%$ Respondents } & \multirow[b]{2}{*}{ Mean } & \multirow[b]{2}{*}{ SD } & \multirow[b]{2}{*}{$\begin{array}{c}\text { Alpha if } \\
\text { deleted }\end{array}$} \\
\hline & & $\begin{array}{l}\text { Great } \\
\text { extent }\end{array}$ & $\begin{array}{l}\text { Some } \\
\text { extent }\end{array}$ & $\begin{array}{l}\text { Very } \\
\text { little }\end{array}$ & $\begin{array}{c}\text { Not at } \\
\text { all }\end{array}$ & & & \\
\hline Attend route development networking events & 112 & 64 & 19 & 8 & 10 & 1.7 & .993 & .805 \\
\hline Meet airlines in their offices and present to them & 112 & 55 & 24 & 12 & 9 & 1.8 & .989 & .799 \\
\hline Target a specific airline with a bespoke report & 112 & 47 & 25 & 15 & 14 & 2.0 & 1.089 & .797 \\
\hline Send marketing materials to airlines by email & 112 & 32 & 39 & 16 & 13 & 2.1 & .997 & .790 \\
\hline Invite target airlines to visit the airport & 112 & 31 & 42 & 19 & 8 & 2.1 & .909 & .799 \\
\hline Present itself on route development websites & 112 & 30 & 22 & 17 & 31 & 2.5 & 1.230 & .808 \\
\hline Hire a consultant to conduct activities & 112 & 24 & 25 & 12 & 39 & 2.7 & 1.221 & .838 \\
\hline Provide information on the airport website & 112 & 16 & 26 & 34 & 25 & 2.7 & 1.017 & .804 \\
\hline Send marketing materials to airlines by post/fax & 112 & 6 & 17 & 30 & 47 & 3.2 & .932 & .816 \\
\hline
\end{tabular}




\begin{tabular}{lllllllll}
\hline Communicate with airlines via social media & 112 & 4 & 20 & 22 & 53 & 3.2 & .923 & .799 \\
\hline
\end{tabular}

Mean $=1$ 'great extent', 2 'some extent', 3 'very little', 4 'not at all'.

Scale reliability of the ten items listed in Table 6 was tested using Cronbach's Alpha. The test indicates a high level of internal consistency (alpha of .822) and the alpha for nine of the items if deleted ranges from .790 to .816 . The item 'hire a consultant to conduct activities' has an alpha of .838. This may mean that airports using a consultant have different patterns of activity to those that conduct route development activities in-house. However, the item has not been deleted on the basis that it would have little effect on scale reliability if deleted. The ten items can therefore be combined to provide an indication of the overall extent to which respondents communicate route development opportunities to airlines with an average score ranging from 1 'to a great extent' to 4 'not at all'. The average for all airports is 2.4 (N 112, SD .640). The Independent Samples t-test indicates a significant difference according to airport size with larger airports averaging 2.2 (N 61, SD .565) compared to 2.6 for smaller airports (N 50, SD .643), $t(109) 3.960$, p.000. This is likely to reflect the more limited internal resources and expertise available for route development at smaller airports.

Average scores by geographic location for the ten items listed in Table 6 suggest a difference between regions. Airports in Europe, where previous studies such as ASM (2009) have suggested that route development activities are more advanced, but also North America, average 2.3 compared to 2.5 for airports in Africa, 2.6 in the Middle East and Latin America/Caribbean, and 2.8 in Asia/Pacific, however, the difference between regions is not significant when tested using ANOVA. Similarly, differences are observed according to the way in which airports are operated with an average of 2.4 for public airports compared to 2.2 for private airports. This would be expected given that private airports are generally found to be more pro-active in their approach to marketing compared to public airports (e.g. see Halpern and Pagliari, 2007), however, the difference is not significant when tested using the Independent Samples t-test.

As mentioned in Section 2, airports communicate essential information that airlines need to encourage them to use the airport. The greatest focus of airports is on providing airlines with information about the airport's catchment area such as population, travel propensity, demographics, business/tourist activity, and surface transport links (68 per cent of respondents provide this 'to a great extent'). This is followed by information about marketing support that may be available such as fee deductions or incentives, joint advertising campaigns, and sharing of market research data (62 per cent), route forecasts such as on the nature of traffic, traffic forecasts, simulated traffic, schedule and load factor ( 57 per cent), and airport facilities and profile such as infrastructure, services and other airlines at the airport (52 per cent).

Airports have less focus on providing a financial evaluation, for instance, on operating costs per block hour, yields, forecast revenues, costs and profits (26 per cent of respondents). This finding is consistent with the findings of Stroud (2013) and supports his argument that airlines are generally not influenced by the financial evaluation of routes by airports something that they are likely and more able to do themselves - and that instead, airlines are more influenced by information about the airport's catchment area characteristics, marketing support that may be available, and the airport's profile and facilities. Such information is often made publicly available by airports, and presented on a business-to-business section of their website. 


\subsection{The importance of route development}

Route development appears to have been given a much higher profile within airports during the last few decades. It would have been difficult to find an airport with a specific team employed to conduct route development activities 20 to 30 years ago, while it can be seen in Table 7 that over half of airports responding to the survey have a route development team, of which 44 per cent have a route development team based at the airport itself, and 10 per cent have a route development team based within the head office of the airport authority. This is especially the case for airports operated by private interests where 86 per cent of airports have their own route development team compared to just 47 per cent of airports operated by public interests. The airport manager and/or a deputy manager is responsible for route development activities at a large proportion of airports (32 per cent), and this is especially the case for smaller airports where the figure increases to 54 per cent. Fourteen per cent of all airports come under 'other', where the main responsibility for route development is either with another department at the airport, another department based within the head office of the airport authority, consultants, or as a partnership with a promotion board or regional development agency. The use of consultants was only reported for smaller airports operated by public interests.

Table 7

Main responsibility for route development activities at airports.

\begin{tabular}{|c|c|c|c|c|c|}
\hline & \multicolumn{4}{|c|}{$\%$ Respondents } & \multirow[b]{2}{*}{$\begin{array}{l}\text { Pearson's Chi- } \\
\text { Square }\left(X^{2}\right)\end{array}$} \\
\hline & $\mathrm{N}$ & $\begin{array}{l}\text { Route } \\
\text { development team }\end{array}$ & $\begin{array}{l}\text { Airport } \\
\text { manager/deputy }\end{array}$ & Other & \\
\hline All airports & 116 & 54 & 32 & 14 & \\
\hline By airport size & & & & & $32.847(2)$, p.000 \\
\hline Larger & 64 & 78 & 14 & 8 & \\
\hline Smaller & 52 & 25 & 54 & 21 & \\
\hline By ownership of the operator ${ }^{a}$ & & & & & 10.686(2), p.005 \\
\hline Public & 95 & 47 & 36 & 17 & \\
\hline Private & 21 & 86 & 14 & 0 & \\
\hline
\end{tabular}

The human resources devoted to route development activities have increased in recent years. 116 airports responding to the survey provided data on the number of employees (nearest average number of full-time equivalents/FTEs) that worked specifically with route development in 2013 compared to 2008. There were a total of 416 FTEs in 2013 compared to 361 in 2008. This provides an average of 3.6 FTEs per airport in 2013 compared to 3.1 in 2008 , and when concentrating on the middle 50 per cent of responses in order to exclude any extreme cases, the average is 3.0 FTEs in 2013 compared to 2.0 in 2008. The Independent Samples t-test reveals significant differences according to airport size with an average of 3.2 FTEs in 2013 for smaller airports (N 52, SD 2.194) compared to 3.9 for larger airports (N 64, SD 1.868), t(114)-2.027, p.045. Airports have experienced an overall increase in route development FTEs of 15 per cent during the last five years. The number of FTEs has increased at 42 per cent of airports, remained the same at 47 per cent, and declined at 11 per cent.

Sixty-nine airports responding to the survey provided data about expenditure on route development. The average expenditure on route development (excluding personnel costs) is US $\$ 346,645$. Expenditure ranges from US\$0 to over US\$4 million so the standard deviation is very large when comparing airports. Average expenditure is greater at larger and privately operated airports but per passenger expenditure is lower (see Table 8). Despite the 
importance of route development, expenditure on such activities form only a very small proportion of the total operating cost (TOC) at airports. Expenditure is less than one per cent of TOC at 54 per cent of airports, less than two per cent at 77 per cent of airports, less than three per cent at 84 per cent of airports, and less than four per cent at 88 per cent of airports. Only 12 per cent of airports reported expenditure to be four per cent or more of TOC.

Table 8

Expenditure on route development (excluding personnel costs) at airports during the last financial year.

\begin{tabular}{llll}
\hline & $\mathrm{N}$ & $\begin{array}{l}\text { Average expenditure } \\
\text { (US\$) }\end{array}$ & $\begin{array}{l}\text { Average expenditure per passenger } \\
\text { (US\$) }\end{array}$ \\
\hline All airports & 69 & 346,645 & 0.84 \\
By airport size & & & \\
$\quad$ Smaller & 37 & 104,400 & 1.42 \\
$\quad$ Larger & 32 & 626,741 & 0.17 \\
By ownership of the operator & & & \\
$\quad$ Public & 59 & 319,585 & 0.88 \\
$\quad$ Private & 10 & 506,299 & 0.63 \\
\hline
\end{tabular}

\section{Conclusion}

This paper provides a much-needed assessment of airport route development practice because whilst route development is a well-known concept within the airport industry, there has been scant academic or industry research on the topic. Through the findings of an online survey of 124 airports worldwide, this paper sheds some light on the objectives of airport route development, the most common methods used, and the general level of involvement. However, readers should note that the findings are biased towards mid-sized airports and airports in Europe and North America - possibly because they are more active in route development, and therefore more interested in taking part in the survey.

The results demonstrate that the vast majority airports are now actively involved in route development for a range of objectives and that the process and level of involvement is generally quite extensive, although this often depends on airport characteristics such as its size, geographic location, and the way in which it is operated. It is also likely to depend on the strategic focus of the airport and the business environment within which the airport operates.

The findings contribute to the gap in literature on the subject but may also be used by airport management to further develop their own route development strategy and for learning from industry best practice. This will be particularly relevant to airports that are less advanced in their route development activities. It will also be important to airports seeking to debate route and tourism development strategies with their stakeholders. Indeed, a number of respondents provided feedback to a summary of the findings that was sent to them shortly after completing the survey, and one of them commented that: "Some of the results revealed in the survey are very useful and will certainly help airports in their internal discussions on the way they structure and steer their route development activities. It is also helpful to be presented to the airports' shareholders during strategic debates."

Whilst this paper provides an important contribution to knowledge, it has limitations. In particular, the survey is based on responses from just 124 airports with responses concentrated from airports in Europe and North America where route development practice may be more advanced than in other world regions. Nevertheless, the analysis provides a significant information base from which further studies could be developed. This could 
include both quantitative evaluations using more explicative models, and an additional qualitative approach to get a richer understanding of route development activities.

Specific recommendations emerge when considering future research in this important area. The most obvious is to investigate key factors for successful route development including the role that airport strategy and the airport's business environment plays on the relationship between route development practice and performance. It would be worth drawing upon the airline perspective here by investigating which practices have the most influence on their route development decisions and comparing this with the airport view. The focus of this paper is on the airport operator's activities, however, many airport stakeholders are likely to have an interest or even be actively involved with route development so the role of stakeholders in the route development process, particular those related to the tourism sector, is also worth investigating.

Up until comparatively recently, route development was primarily considered to be an airline function, and airports largely responded to requests from airlines rather than proactively seeking their business. Few airports practiced the art of route development. This paper shows that airports have clearly entered a new era in route development practice that is underpinned by intelligence-based and highly targeted and proactive approaches, especially to personal selling, and from a growing and dedicated team of airport route development personnel. This relatively new area of airport management is likely to spread and continue to evolve as more airports worldwide seek to develop their provision of air services and expertise in route development.

\section{References}

ASM. (2013). The next era of route development - what airlines are telling us, in R. Maslen ASM Survey Provides Guidance to World Routes Airport Delegates, WWW document. URL: http://www.routesonline.com/news/29/breaking-news/216583/asm-survey-providesguidance-to-world-routes-airport-delegates-/. Accessed 24 May 2014.

ASM. (2009). Industry Trends and Climate Survey: Interim Research Results, Live Webinar, July.

Barrett, S. (2004). How do the demands for airport services differ between full service carriers and low-cost carriers? Journal of Air Transport Management, 10(1): 33-39.

Budd, L., Francis, G., Humphreys, I. and Ison, S. (2014). Grounded: Characterising the market exit of European low cost airlines, Journal of Air Transport Management, 34(January): 78-85.

Button, K. (2012). Low cost airlines: a failed business model? Transportation Journal, 51(2): 197-219.

Castillo-Manzano, J.I., López-Valpuesta, L. and González-Laxe, F. (2011). The effects of the LCC boom on the urban tourism fabric: The viewpoint of tourism managers, Tourism Management, 32(5): 1085-1095.

de Haan, F. (2012). Airports developing air services for cargo versus passenger airlines, Aerlines Magazine, 22 March, 52: 1-3. 
Fichert, F. and Klophaus, R. (2011). Incentive schemes on airport charges - Theoretical analysis and empirical evidence from German airports, Journal of Air Transport Management, 1(1): 71-79.

Forsyth, P., Gillen, D., Mueller, J. and Niemeier, H-M. (eds) (2010). Airport Competition, Aldershot: Ashgate.

Francis, G., Fidato, A. and Humphreys, I. (2003). Airport-airline interaction: the impact of low-cost carriers on two European airports, Journal of Air Transport Management, 9(4): 267273.

Graham, A. (2014). Managing Airports: An International Perspective, 4th Edition, Abingdon: Routledge.

Graham, A. (2013). Understanding the low cost carrier and airport relationship: A critical analysis of the salient issues, Tourism Management, 36: 66-76.

Graham, A. and Dennis, N. (2010). The impact of low cost airline operations to Malta, Journal of Air Transport Management, 16(1): 127-136.

Griffin, T. (2012). Route to success, Airport World, August-September, 17(4): 56-58.

Halpern, N. (2010). The marketing of small regional airports, in G. Williams and S. Bråthen (eds) Air Transport Provision in Remoter Regions, Farnham: Ashgate.

Halpern, N. and Graham, A. (2013). Airport Marketing, Abingdon: Routledge.

Halpern, N., Graham, A. and Davidson, R. (2012). Meetings facilities at airports, Journal of Air Transport Management, 18(1): 54-58.

Halpern, N. and Pagliari, R. (2007). Governance structures and the market orientation of airports in Europe's peripheral areas, Journal of Air Transport Management, 13(6): 376-382.

Hargrove, M.R. (2010). Airport incentive programs: legal and regulatory considerations in structuring programs and recent survey observations, 2010 ACI North America Airport Economics and Finance Conference, Miami, May.

Hvass, K.A. (2013). To fund or not to fund: A critical look at funding destination marketing campaigns, Journal of Destination Marketing \& Management, in press.

Kramer, L., Fowler, P., Hazel, R., Ureksoy, M. and Harig, G. (2010). ACRP Report 28: Marketing Guidebook for Small Airports, Washington, D.C.: Transportation Research Board.

Malina, R., Albers, S. and Kroll, N. (2012). Airport incentive programmes: A European perspective, Transport Reviews, 32(4): 435-453.

Martin, S.C. (2009). ACRP Report 18: Passenger Air Service Development Techniques, Washington, D.C.: Transportation Research Board. 
Pagliari, R. (2005). Developments in the supply of direct international air services from airports in Scotland, Journal of Air Transport Management, 11(4): 249-257.

Smyth, A., Christodoulou, G., Dennis, N., Al-Azzawi, M. and Campbell, J. (2012). Is air transport a necessity for social inclusion and economic development? Journal of Air Transport Management, 22: 53-59.

STRAIR. (2005). Air Service Development for Regional Agencies: Strategy, Best Practice and Results, STRAIR.

Stroud, D. (2013). Going places, Airport World, August-September, 18(4): 59-63.

Thelle, M.H., Pedersen, T.T. and Harhoff, F. (2012). Airport Competition in Europe, Copenhagen: Copenhagen Economics.

Tretheway, M. and Kincaid, I. (2010). Competition between airports: occurrence and strategy in P. Forsyth, D. Gillen, J. Müller and H-M. Niemeier (eds) Airport Competition: The European Experience, Farnham: Ashgate.

Weatherill, J. (2009). Establishing a contemporary airport route development strategy in Graham, A (ed) Latest Thinking in Airport Marketing: Gaining a Competitive Edge in Today's Changing Industry Environment, Marketing and Management Collection, London: Henry Stewart Talks.

Weatherill, J. (2006). North American airline incentives: Best practices and emerging trends, Journal of Airport Management, 1(1): 25-37. 